\title{
MINERAL COMPOSITION OF HIGH BLUEBERRY LEAVES AND FRUITS DEPENDING ON SUBSTRATE TYPE USED FOR CULTIVATION*
}

\author{
Ireneusz Ochmian, Józef Grajkowski, \\ Grzegorz Mikiciuk, Krystyna Ostrowska, \\ Piotr Chełpiński \\ Pomology Department \\ West Pomeranian University of Technology in Szczecin
}

\begin{abstract}
In 2004-2006, an experiment was established at the Experimental Station Rajkowo belonging to the Agricultural University (West Pomeranian University of Technology) in Szczecin. High blueberry bushes were planted in an alkaline reaction ( $\mathrm{pH} 7.1$ ) heavy soil using three different substrates. The bushes were planted in trenches filled with peat, cocoa husk and sawdust. The fertilization of the plants was limited to a sole nitrogen supply (30 kg N ha-1), because chemical analyses of both the soil and the substrates showed high and/or moderate content of other nutrients. In order to decrease cocoa husk reaction and to maintain the reaction of peat and sawdust, the bushes were irrigated with $\mathrm{H}_{2} \mathrm{SO}_{4}$ acidified water up to $\mathrm{pH}$ 2.5-3.5.

The bed prepared of cocoa husk was characterized by the highest $\mathrm{N}$ ( $\left.23.8 \mathrm{mg} 100 \mathrm{~g}^{-1}\right)$, $\mathrm{Zn}$ content $(51.6 \mathrm{mg} \mathrm{kg}-1)$, and $\mathrm{pH}$ (5.0). On the other hand, sawdust substrate had the lowest salinity $\left(0.35 \mathrm{~g} \mathrm{NaCl} \mathrm{kg}^{-1}\right)$. Sawdust substrate showed the highest level of $\mathrm{Mn}$

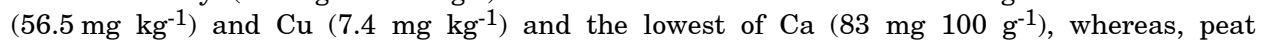
substrate showed the highest salinity $\left(0.87 \mathrm{~g} \mathrm{NaCl} \mathrm{kg}^{-1}\right)$ and the lowest $\mathrm{pH}$ (3.8). The usage of cocoa husk substrate resulted in the highest content of $\mathrm{N}(23.6), \mathrm{K}\left(6.9 \mathrm{~g} \mathrm{~kg}^{-1}\right)$ and Mn (104.5 mg kg-1) in cv. Sierra blueberry leaves as well as N (16.0) and K $\left(6.5 \mathrm{~g} \mathrm{~kg}^{-1}\right)$ in berries. The plants grown in sawdust substrate showed the highest level of $\mathrm{Ca}\left(1.75 \mathrm{~g} \mathrm{~kg}^{-1}\right)$, $\mathrm{Cu}(3.2)$ and $\mathrm{Zn}\left(12.4 \mathrm{mg} \mathrm{kg}^{-1}\right)$, in the leaves as well as $\mathrm{S}(1.7)$ and $\mathrm{Cu}\left(3.5 \mathrm{mg} \mathrm{kg}^{-1}\right)$ in berries.
\end{abstract}

Key words: highbush blueberry, macro-, microelements, substrates, leaves, fruit.

dr Ireneusz Ochmian, Pomology Departament, West University of Technology, ul. Janosika 8, 71-424 Szczecin, Poland, phone: 09144961 63, e-mail: ochmian@go2.pl, ireneusz.ochmian@zut.edu.pl

*The study was supported by the grant of the Scientific Research Committee No.0395/P06/ 2004/26. 


\author{
Abstrakt
}

W latach 2004-2006, w Sadowniczej Stacji Badawczej Katedry Sadownictwa Akademii Rolniczej w Szczecinie (obecnie Zachodniopomorski Uniwersytet Technologiczny), posadzono krzewy borówki wysokiej na glebie zwięzłej o odczynie zasadowym (pH 7,1) z zastosowaniem trzech różnych rodzajów podłoża. Krzewy posadzono w rowy wypełnione torfem, przekompostowaną łuską kakaową oraz trocinami z drzew iglasto-liściastych. Nawożenie roślin ograniczono do azotu (saletra amonowa $30 \mathrm{~kg} \mathrm{~N} \mathrm{ha}^{-1}$ ), z powodu wysokiej lub/i średniej zawartości pozostałych składników pokarmowych w glebie oraz podłożach. W celu obniżenia (łuska kakaowa) lub utrzymania niskiego odczynu podłoża (torf, trociny) w czasie okresu wegetacji krzewy nawadniano wodą zakwaszana $\mathrm{H}_{2} \mathrm{SO}_{4}$ do odczynu 2,3-3,9.

Podłoże przygotowane $\mathrm{z}$ łuski kakaowej miało najwyższą zawartość azotu (23,8 mg $\left.100 \mathrm{~g}^{-1}\right)$, cynku (51,6 mg kg-1) oraz najwyższe $\mathrm{pH}(5.0)$, ponadto zawierało najmniej soli $\left(0,35 \mathrm{~g} \mathrm{NaCl} \mathrm{kg}^{-1}\right)$. Podłoże przygotowane $\mathrm{z}$ trocin zawierało najwięcej manganu $(56,5 \mathrm{mg}$ $\mathrm{kg}^{-1}$ ) i miedzi (7,4 mg kg-1) oraz najmniej wapnia (83 mg $100 \mathrm{~g}^{-1}$ ), natomiast było najbardziej zasolone $(0,87 \mathrm{~g} \mathrm{NaCl} \mathrm{kg-1)}$ i miało najniższy odczyn (3,8). Krzewy odmiany Sierra posadzone w łusce kakaowej zawierały najwięcej azotu $(23,6)$, potasu $\left(6,9 \mathrm{~g} \mathrm{~kg}^{-1}\right)$ i manganu $\left(104,5 \mathrm{mg} \mathrm{kg}^{-1}\right)$ w liściach oraz azotu $(16,0)$ i potasu $\left(6.5 \mathrm{~g} \mathrm{~kg}^{-1}\right)$ w owocach. Natomiast rośliny posadzone $\mathrm{w}$ trocinach zawierały najwięcej wapnia $\left(1,75 \mathrm{~g} \mathrm{~kg}^{-1}\right)$, miedzi $(3,2) \mathrm{i}$ cyn$\mathrm{ku}\left(12,4 \mathrm{mg} \mathrm{kg}^{-1}\right) \mathrm{w}$ liściach oraz siarki $(1,7) \mathrm{i}$ miedzi $\left(3,5 \mathrm{mg} \mathrm{kg}^{-1}\right)$ w owocach.

Słowa kluczowe: borówka wysoka, makro- i mikroelementy, podłoże, liście, owoce.

\title{
INTRODUCTION
}

Fruits of high blueberry are appreciated for their good taste and processing value as well as their dietary and healthy virtue. Because of its value, the species has been cultivated for years in North America. The first breeding project was launched in 1908 in Florida (LYRENE 1997) and from the USA highbush blueberries were imported to Europe (STRIK 2005). In Poland, first experiments on highbush blueberry cultivation were undertaken in 1946, although the development of large-scale production methods started in 1976 (SMOLARz 2006). In recent years, considerable increase in blueberry production has been observed in Poland. In 2005, blueberry production in Poland was 3,500 $\mathrm{t}$ and in 2006 the growing area covered 2,100 ha (ENTROP 2006).

All plants of the Ericaceae family species have specific soil requirements, different from those of other orchard plants. The bushes are widespread in pine forests on acid and moisture soils (BLASING et al. 1987). Because such soils are less and less available, establishing new plantations has become more and more difficult. It is thought that cropping this plant is possible on mineral soil which is irrigated and bedded (Moore 1993). In the United States, cotton by-products, pecan hulls (KREWER et al. 2002), pit-coal ash, sludge from sewage-treatment plants as well as peat are used for mulching (PliszkA 1977). 
Fertilization needs of the berries are not high in comparison with other species, but they are specific. The basic fertilizer component in berry cropping is nitrogen (KoZIŃSKI 2006, KREWER and NeSMITH). When a plantation is covered by a sawdust bed, all fertilizer doses need to be increased by 50 $100 \%$. The berry does not require much phosphorus and displays no response to phosphorus fertilization (ECK 1985). It is highly recommendable to double fertilizer doses on peat soil (Ostrowski and MazurczaK 1991). Abundance of beds and soil in chemical components depends much on their origin, cultivation technology and, first of all, fertilization and irrigation (BRYLA 2008, KREWER and NeSmith).

From the practical and economical point of view, the components used for mulching should be relatively cheap, easily accessible, and should meet habitat requirements of the species. Therefore, the usage of agricultural and forest by-products for this purpose seems to be especially justified. The objective of the present study was to evaluate different substrates (cocoa husk, sawdust and peat) on chemical composition of fruits and leaves of highbush blueberry cv Sierra.

\section{MATERIAL AND METHODS}

The experiment was carried out in 2004-2006 at the Experimental Station Rajkowo belonging to the Agricultural University (West Pomeranian University of Technology) in Szczecin. The purpose of the field trial was to evaluate highbush blueberry cultivation in a neutral reaction $(\mathrm{pH} 7.1)$ heavy soil using three different substrates. Bushes of cv. Sierra were planted in ditches $35 \mathrm{~cm}$ deep and $100 \mathrm{~cm}$ wide filled by substrates. In this culture system, three types of substrates were used: acid muck soil (peat), conifer sawdust obtained from a local sawmill, and cocoa husk, a by-product obtained from Gryf Chocolate Confectionary Plant in Szczecin.

Table 1

Physicochemical properties of substrates used in the experiment

\begin{tabular}{|l|c|c|c|}
\hline \multicolumn{1}{|c|}{ Specification } & Peat & Cocoa husk & Sawdust \\
\hline Field water capacity $\left(\% \mathrm{vv}^{-1}\right)$ & 44.8 & 36.9 & 31.3 \\
\hline Full water capacity $\left(\% \mathrm{vv}^{-1}\right)$ & 80.6 & 85.3 & 82.6 \\
\hline $\mathrm{pH}^{*}$ & 3.8 & 5.0 & 4.7 \\
\hline Soil salinity $\left(\mathrm{g} \mathrm{NaCl} \mathrm{kg}^{-1}\right)$ & 0.87 & 0.35 & 0.56 \\
\hline
\end{tabular}

*The substrates reaction was measured in $\mathrm{KCl}$ at the end of highbush blueberry vegetative season. 
Among the substrates tested, the greatest field water capacity was found for peat $(44.8 \%)$ and the least for sawdust (31.3\%). Regarding full water capacity, cocoa husk substrate was predominant (85.3\%). These differences necessitated diversifying the watering of the substrates (Table 1).

Water used for peat substrate irrigation had higher $\mathrm{pH}$ (3.7-3.9) because peat reaction was suitable for blueberry cultivation. For cocoa husk and sawdust substrates, water of $\mathrm{pH} \sim 2.4$ was used to depress reaction of these substrates (Table 2). Among the substrates tested, the peat maintained a constant $\mathrm{pH} 3.8$ during field trial, while the highest reaction throughout all the experiment was observed for cocoa husk substrate ( $\mathrm{pH} 5)$.

Table 2

Physicochemical properties of water used in the experiment

\begin{tabular}{|c|c|c|c|c|c|c|c|}
\hline \multicolumn{4}{|c|}{ Raw water } & \multicolumn{2}{c|}{$\begin{array}{c}\text { Acidified water } \\
\text { for sawdust and cocoo } \\
\text { husk }\end{array}$} & \multicolumn{2}{|c|}{$\begin{array}{c}\text { Acidified water } \\
\text { to irrigate peat }\end{array}$} \\
\hline $\begin{array}{c}\mathrm{Fe}^{+3} \\
\left(\mathrm{mg} \mathrm{l}^{-1}\right)\end{array}$ & $\begin{array}{c}\mathrm{Ca}^{+2} \\
(\mathrm{mg} 11)\end{array}$ & $\begin{array}{c}\mathrm{EC} \\
\left(\mathrm{mS} \mathrm{cm}^{-1}\right)\end{array}$ & $\mathrm{pH}$ & $\begin{array}{c}\mathrm{EC} \\
\left(\mathrm{mS} \mathrm{cm}^{-1}\right)\end{array}$ & $\mathrm{pH}$ & $\begin{array}{c}\mathrm{EC} \\
\left(\mathrm{mS} \mathrm{cm}^{-1}\right)\end{array}$ & $\mathrm{pH}$ \\
\hline 0.17 & 94.0 & 0.80 & 7.01 & 2.46 & 2.36 & 2.01 & 3.72 \\
\hline
\end{tabular}

The supplemental irrigation was applied through the drip line type T-Tape with acidified water (with $\mathrm{H}_{2} \mathrm{SO}_{4}$ up to $\mathrm{pH}$ 2.5-3.9 measured in $\mathrm{H}_{2} \mathrm{O}$ ). The intensity of water supply was adjusted to soil moisture by means of the tensiometer monitoring twice a week. Measuring tubes $(30 \mathrm{~cm})$ were installed $15 \mathrm{~cm}$ below the soil surface and $2.2 \mathrm{PF}$ was used as a threshold value for irrigation. Having reached the threshold, the soil was irrigated to approximately 1.0 PF.

The fertilization of the plants was limited to nitrogen supply only because chemical analyses of both the soil and the substrates showed high and/or moderate content of other nutrients. Each type of media used in the raised bed system was fertilized with the ammonium nitrate on three occasions at a total dose of $30 \mathrm{~kg} \mathrm{~N} \mathrm{ha}{ }^{-1}$. The fertilizer was spread evenly on the bed tops at the width of $1 \mathrm{~m}$.

The chemical analyses were carried out on the leaves and fruits collected from 4-6 year old bushes. One hundred leaves out of plants growing on a particular substrate were sampled each year at the beginning of August for chemical analyses. The fruits of each harvest in the season were packed in polyethylene bags $(250 \mathrm{~g})$ and kept frozen $\left(-25^{\circ} \mathrm{C}\right)$ until analyzed. Having completed fruit collecting, all fruit samples were combined, thawed at room temperature and then dried. The dried fruit were pulverized. The content of macro- and microelements was determined according to the Polish Standards. Total nitrogen content was determined with Kjeldahl's method. The content of $\mathrm{K}$ and $\mathrm{Ca}$ was measured with the atomic emission spectrometry, 
whereas $\mathrm{Mg}, \mathrm{Cu}, \mathrm{Zn}, \mathrm{Fe}$ and $\mathrm{Mn}$ content was determined with the flame atomic absorption spectroscopy. Phosphorus content was determined with Barton's method.

The results were subjected to statistical analysis using Statistica 7.1. Each year, the study trial consisted of a a randomized block design in three replications. The analysis of variance in the form of 3-year synthesis for a fixed model was used. The values were evaluated by Duncan's test and the differences at $P<0.05$ were considered significant.

\section{RESULTS AND DISCUSSION}

The cocoa husk bed showed higher content of available $\mathrm{P}(17.16 \mathrm{mg}$ $100 \mathrm{~g}^{-1}$ ) compared to sawdust (7.54 mg $\left.100 \mathrm{~g}^{-1}\right)$, although both substrates were not significantly different from peat (Table 3). During the experiment, this form of phosphorus significantly decreased in the peat bed because of irrigating with acidified water. In contrast, it increased in the cocoa husk bed (data not presented). The higher level of $\mathrm{P}$ in cocoa husk could be an after-effect of mineralization of organic matter. MERCIK and SAS (1998) also observed that $\mathrm{P}$ content decreased in low $\mathrm{pH}$ beds, although visual evaluation of plants and analyses of leaves did not prove any deficiency of this element.

Table 3

Content of soil reaction, absorbing macro- and microelements in used beds - synthesis of years 2004-2006

\begin{tabular}{|c|c|c|c|}
\hline $\begin{array}{c}\text { Macro- and } \\
\text { microelements }\end{array}$ & Peat & Sawdust & Cocoa husk \\
\hline \multicolumn{4}{|c|}{${\mathrm{mg} 100 \mathrm{~g}^{-1}}$} \\
\hline Total N & $11.18 b^{*}$ & $6.20 a$ & $23.84 c$ \\
\hline $\mathrm{P}$ & $13.04 a b$ & $7.54 a$ & $17.16 b$ \\
\hline $\mathrm{K}$ & $29.65 a$ & $52.49 b$ & $51.26 b$ \\
\hline $\mathrm{Ca}$ & $170.1 b$ & $83.4 a$ & $208.5 b$ \\
\hline $\mathrm{Mg}$ & $28.62 a \quad 21.94 a$ & $26.71 a$ \\
\hline \multicolumn{5}{|c|}{$\mathrm{mg} \mathrm{kg}^{-1}$} \\
\hline $\mathrm{Cu}$ & $1.81 a$ & $7.36 b$ & $51.66 b$ \\
\hline $\mathrm{Zn}$ & $202 a$ & $25.93 a$ & $279 b$ \\
\hline $\mathrm{Fe}$ & $32.03 a$ & $231 a b$ & $24.13 a$ \\
\hline $\mathrm{Mn}$ &
\end{tabular}

*Means values marked with the same letter do not differ significantly at $P<0.05$ according to Duncan range test. 
The level of $\mathrm{K}$ found in the peat bed was over two-fold lower than in

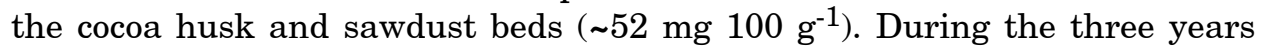
of the experiment, $\mathrm{K}$ level also decreased in the substrates due to the uptake by plants and migration into deeper layers of the soil. However, its content in the beds met fertilizer requirements of the plants.

The peat and cocoa husk substrates were characterized by higher Ca content. Moreover, cocoa husk showed highest N, Zn, and Fe content, whereas sawdust had the highest level of $\mathrm{Mn}$ and $\mathrm{Cu}$.

In general, the leaves exhibited higher accumulation of macro- and microelements compared to berries (Table 4). Both leaves and fruits originating from bushes grown in cocoa husk substrate were characterized by the highest total $\mathrm{N}\left(23.56\right.$ and $\left.16.03 \mathrm{~g} \mathrm{~kg}^{-1}\right)$ and $\mathrm{K}\left(6.87\right.$ and $\left.6.54 \mathrm{~g} \mathrm{~kg}^{-1}\right)$ content. According to HANSON (2006), the sufficient range of $\mathrm{N}$ for leaves collected in mid-summer is between 1.7-2.1\%. In this assay, all the plants showed similar or higher values. On the other hand, nitrogen content in fruit varied from $1.4 \%$ (14.22 $\mathrm{g} \mathrm{kg}^{-1}$ ) to $1.6 \%$ (16.03 $\left.\mathrm{g} \mathrm{kg}^{-1}\right)$; for comparison, SkUPIEN (2004) obtained 1.7-2.8\% $\mathrm{N}$ divergence in four cultivars of blueberries. The highest $\mathrm{P}$ content was found in the leaves of plants grown in the cocoa husk bed and the lowest in that of sawdust. The fruit-P was not substrate dependent.

Macro- and microelements content in leaf and fruit of blueberry

'Sierra' cultivar - synthesis of years 2004-2006

\begin{tabular}{|c|c|c|c|c|c|c|}
\hline \multirow{2}{*}{\begin{tabular}{c} 
Macro- $\begin{array}{c}\text { L } \\
\text { and } \\
\text { microelements* }\end{array}$ \\
\cline { 2 - 7 }
\end{tabular}} & peat & sawdust & cocoa husk & peat & sawdust & cocoa husk \\
\cline { 2 - 7 } g kg-1.w. & \multicolumn{5}{|c|}{ d.wuit } \\
\hline Total N & $21.79 a$ & $21.03 a$ & $23.56 b$ & $14.53 a$ & $14.22 a$ & $16.03 b$ \\
\hline $\mathrm{P}$ & $1.08 a b$ & $0.91 a$ & $1.22 b$ & $1.06 a$ & $1.07 a$ & $1.15 a$ \\
\hline $\mathrm{K}$ & $5.66 a$ & $5.53 a$ & $6.87 b$ & $5.99 a$ & $5.90 a$ & $6.54 b$ \\
\hline $\mathrm{Ca}$ & $0.75 a$ & $1.75 b$ & $0.90 a$ & $0.10 a$ & $0.10 a$ & $0.06 a$ \\
\hline $\mathrm{Mg}$ & $1.03 a$ & $1.18 a$ & $1.02 a$ & $0.40 a$ & $0.39 a$ & $0.34 a$ \\
\hline $\mathrm{S}$ & $2.20 b$ & $1.66 a$ & $1.48 a$ & $1.16 a$ & $1.68 b$ & $1.16 a$ \\
\hline $\mathrm{Cu}$ & $0.92 a$ & $3.24 b$ & $1.28 a$ & $0.79 a$ & $3.52 b$ & $1.35 a$ \\
\hline $\mathrm{Zn}$ & $9.09 a$ & $12.38 b$ & $10.10 a$ & $6.31 a$ & $11.31 b$ & $11.37 b$ \\
\hline $\mathrm{Fe}$ & $58.74 a$ & $62.90 b$ & $60.50 a b$ & $22.37 a$ & $29.92 b$ & $26.40 a b$ \\
\hline $\mathrm{Mn}$ & $73.86 a$ & $89.56 b$ & $104.47 c$ & $33.62 c$ & $27.21 b$ & $21.55 a$ \\
\hline
\end{tabular}

*The values are presented on dry weight basis. 
Further, the largest amount of $\mathrm{Ca}$ was found in the leaves of plants cultivated in sawdust $\left(1.75 \mathrm{~g} \mathrm{~kg}^{-1}\right)$ whereas for fruits it was at an approximate level regardless the bed used (0.06-0.1 $\left.\mathrm{g} \mathrm{kg}^{-1}\right)$. Both for leaves and fruits no effect of substrate was observed regarding $\mathrm{Mg}$ level. For 'the cultivars Spartan, Bluecrop, Jersey and Blueray SkuPIEŃ (2004) determined lower $\mathrm{Mg}$ content in fruit (0.16-0.18 $\mathrm{g} \mathrm{kg}^{-1}$ f.w. after recalculation).

The usage of peat in the assay favored $\mathrm{S}$ accumulation in the leaves $\left(2.20 \mathrm{~g} \mathrm{~kg}^{-1}\right)$ whereas the usage of sawdust enhanced $\mathrm{S}$ level in berries $(1.68 \mathrm{~g}$ $\mathrm{kg}^{-1}$ ) compared to other substrates. GLONEK and Komosa (2006) found 1.1$-1.2 \mathrm{~g} \mathrm{~S} \mathrm{~kg}^{-1}$ leaf d.w. (after recalculation) irrespective of the fertilization rate applied.

The highest level of $\mathrm{Cu}$ was measured in leaves and fruit when the sawdust medium was used (3.24 and $3.52 \mathrm{mg} \mathrm{kg}^{-1}$, respectively). Regarding $\mathrm{Zn}$ content, it was the highest in leaves of plants grown in sawdust $(12.38 \mathrm{mg}$ $\mathrm{kg}^{-1}$ ) and berries of plants on the cocoa husk and sawdust substrates $(\sim 11.3$ $\left.\mathrm{mg} \mathrm{kg}{ }^{-1}\right)$. SkUPIEŃ (2004) found much lower fruit $\mathrm{Cu}\left(0.17-0.30 \mathrm{mg} \mathrm{kg}^{-1}\right.$ f.w.) and $\mathrm{Zn}$ range (1.08-1.30 $\mathrm{mg} \mathrm{kg}^{-1}$ f.w.).

The leaves and fruits of bushes grown in sawdust showed the highest Fe content (62.9 and $29.9 \mathrm{mg} \mathrm{kg}^{-1}$, respectively) whereas the lowest iron concentration was found in plants grown in peat $\left(58.7\right.$ and $22.4 \mathrm{mg} \mathrm{kg}^{-1}$, respectively). Over 36-37 $\mathrm{gg} \mathrm{g}^{-1}$ of iron was found by MERHAUT and DarNELL (1996).

The use of cocoa husk enhanced Mn (104.47 $\mathrm{mg} \mathrm{kg}^{-1}$ ) level in leaves, while plants originating from peat showed an increased Mn level in fruits. GloneK and Komosa (2006) found similar Fe (53.9-57.7 $\mathrm{mg} \mathrm{kg}^{-1}$ ) and $\mathrm{Mn}$ (107.6-128.0 mg kg-1) leaf status, which slightly increased in fertilized plants compared to control ones.

\section{CONCLUSIONS}

1. The bed prepared of cocoa husk was characterized by the highest $\mathrm{N}$ and $\mathrm{Zn}$ content and $\mathrm{pH}$ despite substrate irrigation with acidified water $(\mathrm{pH}$ 2.3-2.5) for many years. On the other hand, sawdust substrate had the lowest salinity. Sawdust substrate showed the highest level of $\mathrm{Mn}$ and $\mathrm{Cu}$ and the lowest of $\mathrm{Ca}$, whereas peat substrate showed the highest salinity and the lowest $\mathrm{pH}$.

2. The use of cocoa husk substrate resulted in the highest content of $\mathrm{N}$, $\mathrm{K}$ and $\mathrm{Mn}$ in cv. Sierra blueberry leaves as well as $\mathrm{N}$ and $\mathrm{K}$ in berries.

3. The plants grown in sawdust substrate showed the highest level of $\mathrm{Ca}$, $\mathrm{Cu}$ and $\mathrm{Zn}$ in leaves as well as $\mathrm{S}$ and $\mathrm{Cu}$ in berries. 
4. The three-year study showed that it is possible to cultivate highbush blueberries in clay soil of alkaline reaction provided that the plants be grown in trenches filled with peat or sawdust substrates and drip irrigation with acidified water be applied.

\section{REFERENCES}

Blasing D., Naumann W.D., Hartge K.H. 1987. Einfluss des Standortes auf die Entwicklung von Kulturheidelbeeren (Vaccinium corymbosum L.). I. Erhebung in erwerbsmassig genutzten Kulturheidelbeeranlagen auf humosen Sandboden. Gartenbauwissenschaft, 52 (4): 185-191.

BRYLA, D.R. 2008. Water requirements of young blueberry plants irrigated by sprinklers, microsprays and drip. Acta Hort., 792: 135-139.

Eck, P. 1985. Response of highbush blueberry on a berryland sand to potassium fertilization. Acta Hort., 165: 227-228.

GloneK J., Komosa A. 2006. The effect of fertigation on the nutrient status and yield of highbush blueberry cv. 'Bluecrop'. Acta Hort., 715: 371-374.

ENTROP A-P. 2006. Heidelbeeerlehrfahrt zur "Blueberry World" nach Venlo/ Nlederlande am 23/24.6.2005. Mitt.OVR 61 (1): 19-24.

Hanson E.J. 2006. Nitrogen fertilization of highbush blueberry. Acta Hort., 715: 347-351.

KozINsKi B. 2006. Influence of mulching and nitrogen fertilization rate on growth and yield of highbush blueberry. Acta Hort., 715: 231-236.

Krewer G., Ruter J., NeSmith D. S., Clark J., Otts T., Scarborough S., Mullinix B., Hepp R. F., 2002. Performance of low cost organic materials as blueberry substrates and soil amendments. Acta Hort., 574: 273-279.

Krewer G., NeSmith D. S. Blueberry fertilization in soil. University of Georgia Ext. Fruit Publication 01: 1. http://www.smallfruits.org/Blueberries/production/blueberryfert.pdf .

LyREne PM. 1997. Value of various taxa in breeding tetraploid blueberries in Florida. Euphytica, 94: 15-22.

Mercik S., SAS L. 1998. Ujemny wptyw nadmiernego zakwaszenia gleby na rośliny [Negative influence on excssive acidification of soil on plants]. Zesz. Probl. Post. Nauk Rol., 456: 29-39. [in Polish]

Merhaut D.J. DaRnell R.L. 1996. Vegetative growth and nitrogen/karbon partitioning In blueberry as influence by nitrogen fertilization. J. Amer. Hort. Sci., 121(5): 875-879.

Moore JN. 1993. Adapting low organic upland mineral soils for culture of highbush blueberries. Acta Hort., 346: 221-229.

Ostrowski W., Mazurczak G. 1991. Zaktadanie i prowadzenie towarowej plantacji borówki wysokiej [Establishing and running a commercial plantation of high berry]. AR, Szczecin. [in Polish]

PliszKa, K. 1977. A primary study on growth and development of highbush blueberries in central Poland. Acta Hort., 6: 153-162.

SKuPIEŃ K. 2004. Zawartość wybranych sktadników mineralnych $w$ owocach czterech odmian borówki wysokiej (Vaccinium corymbosum L.) [Content of some mineral components in fruits of four cultivars of high berry (Vaccinium corymbosum L.)]. J. Elementol., 9(1): 43-49. [in Polish]

Smolarz, K. 2006. History of highbush blueberry (V. corymbosum L.) growing in Poland. Acta Hort., 715: 313-316.

StRIK B. 2005. Blueberry: an expanding world berry crop. Chron. Hort., 45 (1): 7-12. 